\title{
NUTRITIONAL POTENTIAL AND FUNCTIONAL PROPERTIES OF TEMPE PRODUCED FROM MIXTURES OF DIFFERENT LEGUMES \\ 1: Chemical constituents of legume mixtures and their tempe
}

(Received:24.7.2006)

\author{
By \\ A. G. Nassar, A.E, Mubarak*, and A. E El-Beltagy** \\ Food Science and Technology Department, Faculty of Agriculture, Al-Azhar University, Assiut, Egypt. \\ * Home Economics Department, Faculty of Specific Education, Menofiya University, Ashmoon, Egypt. \\ ** Food Science and Technology Department, Faculty of Agriculture, Menofiya University,
}

\begin{abstract}
Fermented foods such as Tempe represent technological alternative for a great variety of legumes or combination of them to improve their nutritional quality and to obtain edible products with palatable sensorial characteristics. The chemical composition, i.e., carbohydrate fractions, mineral content and nitrogenous compounds) were determined for different legumes, (faba bean, lupine, chickpea; peas and their mixtures before and after fermentation by Rhizopus oligosporus. Tempe had a higher $(\mathrm{p}<0.05)$ protein and fiber content, compared with their legume mixtures, while it had a lower fat, ash and carbohydrate contents. Also, the levels of reducing sugars, starch and stachyose as well as raffinose were reduced after fermentation. Therefore, non protein nitrogen and protein nitrogen were significantly reduced, while the levels of total nitrogen and true protein were increased.
\end{abstract}

Key words: chemical composition, chick pea, faba bean, lupine, peas, raffinose, stachyose, tempe.

\section{INTRODUCTION}

Legumes are an important source of proteins in the Egyptian diet and in many developing countries. High meat prices during recent years and the need for protein rich foods have led people in most less developed countries to shift their consumption to certain legumes (Askar, 1986).

Fermented foods may be defined as those foods which have been subjected to the action of microorganisms, so that desirable biochemical changes cause significant modification to the food. By fermenting the food it became more nutritional, more digestible and safer or have better flavour. Fermented foods provide a major contribution to the diet in all parts of the world and can be divided into many classes: beverages; cereal products, dairy products; fish products; fruit and vegetable products, legumes and meat products (Campbell-platt, 1987).

Tempe is a traditional Indonesian solidsubstrate fermented product in which soybeans are hydrated and acidified, dehulled, cooked, and then fermented with Rhizopus spp mold. The cotyledon become covered and penetrated by denes white nonsporulated mycelium that binds them into a compact, sliceable mass. Tempe is obtained by fermentation in two stages which consist of soaking process and solid substrate fermentation process with different strains of Rhizopus spp. ( $R$. oligosporus, $R$. arrhizus and $R$. stolonifer) as reported by Nout and Rombouts (1990) and Steinkraus (1996). Other substrates have been used to elaborate tempe: common bean, chickpeas, rapeseed, lupine, horsbean, groundnut, wheat, corn and soybean. The process of tempe requires a relatively simple infrastructure that can produce profound chemical changes that improve the nutritional quality. The tempe manufacture could be an appropriate method for small and medium scale processing of locally available legumes and or cereals into wholesome products of high nutritional value in development countries (Hachmeister and Fung, 1993).

Tempe is widely consumed in Indonesia, the Netherlands and North America. The high protein content and pleasant, relatively bland taste has led to it occupying a small, but expanding part of the vegetarian market in Japan, USA and Europe (Mital and Garg, 1990 and Liu, 1997).

The present work was carried out to produce tempe in a small scale using mixtures of different Egyptian traditional legumes by Rhizopus oligosporus (NRRL 2710). In addition, 
evaluations of the final chemically and nutritionally products were carried out.

\section{MATERIALS AND METHODS}

\subsection{MATERIALS}

Four different kinds of legumes, i.e., Green peas (Pisum sativum) variety Lencolen, broad bean (Vicia faba L.) variety Giza 3, Chickpeas (Cicer aritinum) and Termis (Lupinus termis) were obtained from the Agricultural Research Center, Seeds Department, Giza, Egypt.

Mold strains: Rhizopus oligosporus (NRRL 2710) was obtained from Northern Regional Research Laboratory, Peoria, Illinois, USA. The strain was maintained on slants of potatodextrose- agar (PDA) at $5 \pm 1{ }^{\circ} \mathrm{C}$ and used after 7 days.

\subsection{METHODS}

2.2.1. Inoculum preparation: Inoculum was prepared by suspended each slant with $4 \mathrm{ml}$ sterile distilled water for $2 \mathrm{~min}$ and $1 \mathrm{ml}\left(1 \times 10^{6}\right.$ spores / $\mathrm{ml}$ ) of such suspension was used to inoculate the legume mixtures grits (about $50 \mathrm{~g}$ dry weight).

2.2.2. Tempe preparation: Broad bean and green peas as well as whole sweet termis and Chickpea seeds were individually soaked in tap water (1:20 $\mathrm{w} / \mathrm{v}$ ) at room temperature (about $25^{\circ} \mathrm{C}$ ) for $16 \mathrm{hrs}$. The soaked seeds were dehulled manually and ground into grits using household blender and mixed as follow :

$\begin{array}{ll}\text { Blend 1 } & 100 \% \text { faba bean } \\ \text { Blend 2 } & 75 \% \text { faba bean }+25 \% \text { lupine } \\ \text { Blend 3 } & 75 \% \text { faba bean }+25 \% \text { chickpea } \\ \text { Blend 4 } & 75 \% \text { faba bean }+25 \% \text { peas } \\ \text { Blend 5 } & 50 \% \text { faba bean }+50 \% \text { lupine } \\ \text { Blend 6 } & 50 \% \text { faba bean }+50 \% \text { chickpea } \\ \text { Blend 7 } & 50 \% \text { faba bean }+50 \% \text { peas }\end{array}$

Blend 8 (Mixture) $25 \%$ faba bean $+25 \%$ lupine $+25 \%$ chickpea $+25 \%$ peas

All the previous mixtures were cooked in tap water at $100{ }^{\circ} \mathrm{C}(1: 3 \mathrm{w} / \mathrm{v})$ acidified with $1 \%$ of $85 \%$ lactic acid for $25 \mathrm{~min}$ then cooled to $37{ }^{\circ} \mathrm{C}$ and inoculated with spore suspension, mixed, packing in petri dishes and incubated for $48 \mathrm{~h}$ at $37 \pm 1^{\circ} \mathrm{C}$.

\subsubsection{Proximate analysis}

Moisture content, crude fat, ash, total proteins and non-protein nitrogen were determined according to AOAC (1990). Starch was determined as glucose after hydrolysis by $\mathrm{HCl}$. Reducing sugars were extracted by $70 \%$ ethanol and determined by phenol-sulfuric acid method according to Dubois et al., (1956). Mineral content was determined after digestion by concentrated $\mathrm{HNO}_{3}$ and $\mathrm{HClO}_{4}(1: 1, \mathrm{v} / \mathrm{v})$ for $3 \mathrm{~h}$.
Phosphorus was determined in the digested solution according to the method of Taussky and Shorr (1953). Na and K ions were estimated using emission flame photometer (Model Corning 410, England). The other minerals ( $\mathrm{Zn}, \mathrm{Cu}, \mathrm{Fe}$ and $\mathrm{Mn}$ ) were determined according to Lindsey and Norwell (1969) using absorption spectrophotometer (Perkin-Elmer Instrument Model 2380, USA).

\subsection{Statistical analysis}

The results were expressed as the mean values of three separate determinations, except for the mineral contents. Data were subjected to analysis of variance using a completely randomized design (Steel and Torrie, 1980).

\section{RESULTS AND DISCUSSION}

\subsection{Proximate composition}

Chemical constituents i.e., proteins, fats, fiber, ash and total carbohydrates of legumes and their unfermented as well as fermented mixtures are presented in Tables (1 and 2). Lupine had the higher amount of proteins, fats and fiber compared with other legumes used in this study. The blends containing 50\% faba bean and 50\% lupine had the highest amount of proteins, fats, fiber and ash. On the other hand, after fermentation, crude protein and crude fiber content were significantly increased $(\mathrm{p} \leq 0.05)$. The increasing rate of protein and fiber were ranged between 2.50 to $26.34 \%$ and 17.52 to $111.20 \%$, respectively, while the levels fats, ash and carbohydrates were decreased significantly $(\mathrm{p} \leq 0.05)$. These changes may be due to leaching out of some compounds during boiling before fermentation and to fungal growth and consumption of carbohydrates and fats as source of energy and the development of a fiberrich fungus mycelium (Shurtleff and Aoyagi, 1979). The obtained results agree with those obtained by De-Reu et al. (1995) and El-Bagory et al. (2001).

\subsection{Carbohydrate fractions}

Reducing sugars, starch and oligosaccharides (stachyose and raffinose) of raw beans are illustrated in Table (3). Chickpea and faba bean contained the highest amount of starch (63.57 and 61.55\%), respectively followed by pea $(53.97 \%)$ and lupine $(38.77 \%)$. While, faba bean and peas had the highest amount of reducing sugars. On the other side, lupine and peas had the highest amount of stachyose (2.39 and 2.19\%, respectively), while lupine and faba bean had the highest amount of raffinose. 
Table (1): Chemical composition of raw materials used in tempe preparation.

\begin{tabular}{cccccc}
\hline Legumes & Crude protein & Crude fat & Crude fiber* & Ash & Total carbohydrates \\
\hline Fababean & $25.35 \pm 0.60$ & $1.05 \pm 0.15$ & $3.48 \pm 0.35$ & $3.59 \pm 0.21$ & $66.53 \pm 1.19$ \\
Lupine & $37.72 \pm 0.88$ & $13.62 \pm 0.20$ & $6.39 \pm 0.42$ & $2.73 \pm 0.25$ & $39.90 \pm 0.82$ \\
Chickpea & $21.54 \pm 0.50$ & $5.75 \pm 0.21$ & $4.23 \pm 0.36$ & $2.81 \pm 0.12$ & $65.67 \pm 0.93$ \\
Peas & $32.26 \pm 0.80$ & $2.45 \pm 0.10$ & $4.15 \pm 0.50$ & $3.42 \pm 0.20$ & $57.72 \pm 1.10$ \\
\hline L.S.D.5\% & $\mathbf{0 . 8 8}$ & 0.23 & 0.50 & 0.25 & 1.21 \\
\hline
\end{tabular}

*Calculated by difference

Table (2): Chemical composition of legume mixture and their produced tempe.

\begin{tabular}{|c|c|c|c|c|c|}
\hline Legumes & Crude protein & Crude fat & Crude fiber* & Ash & Total carbohydrates \\
\hline $100 \% \mathrm{FB}$ & $25.35 \pm 0.85$ & $1.05 \pm 0.05$ & $3.48 \pm 0.40$ & $3.59 \pm 0.15$ & $66.53 \pm 1.40$ \\
\hline $75 \% \mathrm{FB}+25 \% \mathrm{~L}$ & $28.44 \pm 1.20$ & $4.20 \pm 0.10$ & $4.35 \pm 0.50$ & $3.30 \pm 0.22$ & $59.87 \pm 0.95$ \\
\hline $75 \% \mathrm{FB}+25 \% \mathrm{C}$ & $24.40 \pm 0.95$ & $2.22 \pm 0.08$ & $3.74 \pm 0.45$ & $3.46 \pm 0.30$ & $66.31 \pm 1.30$ \\
\hline $75 \% \mathrm{FB}+25 \% \mathrm{P}$ & $27.07 \pm 0.76$ & $1.40 \pm 0.07$ & $3.66 \pm 0.40$ & $3.58 \pm 0.21$ & $64.33 \pm 1.12$ \\
\hline $50 \% \mathrm{FB}+\mathbf{5 0} \% \mathrm{~L}$ & $31.53 \pm 1.47$ & $7.30 \pm 0.27$ & $4.97 \pm 0.50$ & $4.50 \pm 0.44$ & $53.22 \pm 0.96$ \\
\hline $\mathbf{5 0 \%} \mathbf{F B}+\mathbf{5 0} \% \mathrm{C}$ & $23.45 \pm 1.10$ & $3.40 \pm 0.12$ & $3.78 \pm 0.38$ & $3.26 \pm 0.22$ & $66.10 \pm 1.15$ \\
\hline $\mathbf{5 0 \%} \mathbf{F B}+\mathbf{5 0} \% \mathrm{P}$ & $28.80 \pm 0.65$ & $1.75 \pm 0.07$ & $3.83 \pm 0.40$ & $3.51 \pm 0.31$ & $62.14 \pm 1.00$ \\
\hline Mixture & $29.21 \pm 0.83$ & $5.71 \pm 0.15$ & $4.57 \pm 0.43$ & $3.16 \pm 0.21$ & $57.45 \pm 0.86$ \\
\hline \multicolumn{6}{|c|}{ Fermented products. } \\
\hline $100 \% \mathrm{FB}$ & $31.41 \pm 1.25$ & $0.62 \pm 0.04$ & $4.09 \pm 0.42$ & $2.25 \pm 0.16$ & $61.63 \pm 0.90$ \\
\hline $75 \% \mathrm{FB}+25 \% \mathrm{~L}$ & $31.60 \pm 0.96$ & $2.17 \pm 0.09$ & $7.36 \pm 0.55$ & $2.05 \pm 0.18$ & $56.82 \pm 1.10$ \\
\hline $75 \% \mathrm{FB}+25 \% \mathrm{C}$ & $30.85 \pm 0.86$ & $1.05 \pm 0.05$ & $5.72 \pm 0.47$ & $1.74 \pm 0.17$ & $60.64 \pm 0.75$ \\
\hline $75 \% \mathrm{FB}+25 \% \mathrm{P}$ & $31.46 \pm 0.80$ & $0.53 \pm 0.03$ & $7.73 \pm 0.60$ & $1.92 \pm 0.12$ & $58.36 \pm 0.66$ \\
\hline $\mathbf{5 0 \%} \mathbf{F B}+\mathbf{5 0} \% \mathrm{~L}$ & $34.89 \pm 1.30$ & $4.89 \pm 0.17$ & $6.53 \pm 0.36$ & $2.17 \pm 0.20$ & $51.52 \pm 0.97$ \\
\hline $50 \% \mathrm{FB}+50 \% \mathrm{C}$ & $28.38 \pm 0.65$ & $2.13 \pm 0.13$ & $6.46 \pm 0.42$ & $1.39 \pm 0.17$ & $61.64 \pm 0.72$ \\
\hline $50 \% \mathrm{FB}+\mathbf{5 0} \% \mathrm{P}$ & $34.30 \pm 0.72$ & $1.06 \pm 0.07$ & $5.13 \pm 0.36$ & $2.38 \pm 0.26$ & $57.13 \pm 0.82$ \\
\hline Mixture & $32.25 \pm 0.80$ & $4.21 \pm 0.16$ & $7.27 \pm 0.58$ & $2.00 \pm 0.12$ & $54.27 \pm 0.58$ \\
\hline L.S.D. 5\% & 1.47 & 0.27 & 0.60 & 0.44 & 1.46 \\
\hline
\end{tabular}

Mixture: $25 \%$ faba bean $+25 \%$ lupine $+25 \%$ Chick pea $+25 \%$ peas

* Calculated by difference

FB ( Faba bean), L ( Lupine), C ( Chickpea), P ( Peas). 
Table (3): Carbohydrate fractions of raw materials used in tempe preparation.

\begin{tabular}{lllll}
\hline Legume & Reducing sugars & Starch & Stachyose & Raffinose \\
\hline Faba bean & $4.98 \pm 0.35$ & $61.55 \pm 0.93$ & $1.85 \pm 0.21$ & $1.06 \pm 0.11$ \\
Lupine & $1.13 \pm 0.12$ & $38.77 \pm 0.78$ & $2.93 \pm 0.26$ & $1.46 \pm 0.16$ \\
Chickpea & $2.10 \pm 0.21$ & $63.57 \pm 0.85$ & $1.63 \pm 0.18$ & $0.99 \pm 0.14$ \\
Peas & $3.75 \pm 0.18$ & $53.97 \pm 0.66$ & $2.19 \pm 0.16$ & $0.81 \pm 0.10$ \\
\hline L.S.D.5\% & $\mathbf{0 . 3 5}$ & 0.93 & 0.26 & 0.16 \\
\hline
\end{tabular}

Table (4): Carbohydrate fractions of legumes mixtures and produced tempe.

\begin{tabular}{lllll}
\hline Legumes & Reducing sugars & Starch & Stachyose & Raffinose \\
\hline $100 \%$ FB & $4.98 \pm 0.41$ & $61.55 \pm 1.23$ & $1.85 \pm 0.18$ & $1.06 \pm 0.15$ \\
$75 \%$ FB+25\% L & $4.06 \pm 0.38$ & $55.85 \pm 1.10$ & $2.12 \pm 0.21$ & $1.16 \pm 0.13$ \\
$75 \%$ FB+25\% C & $4.26 \pm 0.41$ & $62.05 \pm 1.46$ & $1.79 \pm 0.20$ & $1.00 \pm 0.12$ \\
$75 \%$ FB+25\% P & $4.67 \pm 0.36$ & $59.65 \pm 1.12$ & $1.94 \pm 0.18$ & $0.96 \pm 0.11$ \\
$50 \%$ FB+50\% L & $3.06 \pm 0.25$ & $50.16 \pm 0.96$ & $2.39 \pm 0.30$ & $1.30 \pm 0.16$ \\
$50 \%$ FB+50\% C & $3.54 \pm 0.37$ & $62.56 \pm 1.23$ & $1.74 \pm 0.25$ & $1.03 \pm 0.13$ \\
$50 \%$ FB+50\% P & $4.36 \pm 0.44$ & $57.76 \pm 1.05$ & $2.02 \pm 0.26$ & $0.92 \pm 0.15$ \\
Mixture & $3.00 \pm 0.28$ & $54.46 \pm 0.86$ & $2.15 \pm 0.23$ & $1.08 \pm 0.14$ \\
Fermented products. & & & & 0.07 \\
$100 \%$ FB & $2.21 \pm 0.23$ & $59.42 \pm 0.95$ & $0.91 \pm 0.21$ & $0.63 \pm 0.08$ \\
$75 \%$ FB+25\% L & $1.43 \pm 0.21$ & $53.39 \pm 0.82$ & $0.97 \pm 0.17$ & $0.59 \pm 0.07$ \\
$75 \%$ FB+25\% C & $1.51 \pm 0.24$ & $59.13 \pm 0.87$ & $0.82 \pm 0.16$ & $0.44 \pm 0.09$ \\
$75 \%$ FB+25\% P & $1.26 \pm 0.20$ & $57.10 \pm 0.88$ & $0.73 \pm 0.12$ & $0.31 \pm 0.08$ \\
$50 \%$ FB+50\% L & $1.20 \pm 0.17$ & $49.32 \pm 0.75$ & $1.03 \pm 0.15$ & $0.60 \pm 0.10$ \\
$50 \%$ FB+50\% C & $1.17 \pm 0.15$ & $60.47 \pm 1.15$ & $0.64 \pm 0.12$ & $0.49 \pm 0.07$ \\
$50 \%$ FB+50\% P & $1.39 \pm 0.21$ & $55.71 \pm 0.66$ & $0.72 \pm 0.20$ & $0.36 \pm 0.09$ \\
Mixture & $1.41 \pm 0.19$ & $52.86 \pm 0.76$ & $0.85 \pm 0.17$ & $0.21 \pm 0.06$ \\
\hline LSD & 0.44 & 1.47 & 0.30 & 0.16 \\
\hline
\end{tabular}

Mixture: $25 \%$ faba bean $+25 \%$ lupine $+25 \%$ Check pea $+25 \%$ peas

FB ( Faba bean), L ( Lupine), C ( Chickpea), P ( Peas).

Table (5): Mineral content (mg/100g-dry weight basis) of raw materials used in tempe preparation.

\begin{tabular}{lccccccc} 
Legume & Na & K & P & Zn & Mn & Cu & Fe \\
\hline Fababean & 1.20 & 4.13 & $\mathbf{3 . 7 0}$ & $\mathbf{0 . 1 4}$ & $\mathbf{0 . 0 2 3}$ & $\mathbf{0 . 0 2 8}$ & $\mathbf{0 . 5 2}$ \\
Lupine & $\mathbf{1 . 1 3}$ & $\mathbf{7 . 9 0}$ & $\mathbf{1 . 4 4}$ & $\mathbf{0 . 0 9}$ & $\mathbf{0 . 0 7 6}$ & $\mathbf{0 . 0 2 6}$ & $\mathbf{0 . 5 5}$ \\
Chickpea & $\mathbf{0 . 6 0}$ & $\mathbf{5 . 8 0}$ & $\mathbf{1 . 6 0}$ & $\mathbf{0 . 0 5 8}$ & $\mathbf{0 . 0 2 6}$ & $\mathbf{0 . 0 1 3}$ & $\mathbf{0 . 3 2}$ \\
Peas & $\mathbf{0 . 5 7}$ & $\mathbf{9 . 8 0}$ & $\mathbf{3 . 0 6}$ & $\mathbf{0 . 0 9 3}$ & $\mathbf{0 . 0 2 1}$ & $\mathbf{0 . 0 1 9}$ & $\mathbf{0 . 3 9}$ \\
\hline
\end{tabular}


Table (6): Mineral content (mg/100g-dry weight basis) of legume mixture and produced tempe.

\begin{tabular}{|c|c|c|c|c|c|c|c|}
\hline Legume & $\mathrm{Na}$ & $\mathbf{K}$ & $\mathbf{P}$ & Zn & Mn & $\mathrm{Cu}$ & $\mathrm{Fe}$ \\
\hline $100 \%$ FB & 1.2 & 4.13 & 3.70 & 0.14 & 0.023 & 0.023 & 0.52 \\
\hline $75 \% \mathrm{FB}+25 \% \mathrm{~L}$ & 1.04 & 5.06 & 3.15 & 0.13 & 0.021 & 0.027 & 0.53 \\
\hline $75 \% \mathrm{FB}+25 \% \mathrm{C}$ & 0.91 & 4.50 & 3.20 & 0.12 & 0.020 & 0.024 & 0.47 \\
\hline $75 \% \mathrm{FB}+25 \% \mathrm{P}$ & 0.90 & 5.57 & 3.55 & 0.12 & 0.022 & 0.026 & 0.49 \\
\hline $50 \% \mathrm{FB}+50 \% \mathrm{~L}$ & 1.08 & 6.02 & 2.57 & 0.11 & 0.037 & 0.027 & 0.53 \\
\hline $50 \% \mathrm{FB}+50 \% \mathrm{C}$ & 0.80 & 4.98 & 2.66 & 0.10 & 0.025 & 0.020 & 0.42 \\
\hline $50 \% \mathrm{FB}+50 \% \mathrm{P}$ & 0.77 & 6.92 & 3.40 & 0.12 & 0.022 & 0.023 & 0.46 \\
\hline Mixture & 0.83 & 6.90 & 2.47 & 0.09 & 0.020 & 0.021 & 0.45 \\
\hline \multicolumn{8}{|c|}{ Fermented products } \\
\hline $100 \% \mathrm{FB}$ & 0.61 & 2.92 & 2.21 & 0.09 & 0.018 & 0.009 & 0.30 \\
\hline $75 \% \mathrm{FB}+25 \% \mathrm{~L}$ & 0.86 & 4.05 & 1.83 & 0.08 & 0.015 & 0.015 & 0.41 \\
\hline $75 \% \mathrm{FB}+25 \% \mathrm{C}$ & 0.57 & 3.61 & 2.00 & 0.05 & 0.020 & 0.012 & 0.38 \\
\hline $75 \% \mathrm{FB}+25 \% \mathrm{P}$ & 0.58 & 6.25 & 2.58 & 0.06 & 0.018 & 0.017 & 0.37 \\
\hline $50 \% \mathrm{FB}+50 \% \mathrm{~L}$ & 0.72 & 4.04 & 1.82 & 0.070 & 0.029 & 0.011 & 0.43 \\
\hline $50 \% \mathrm{FB}+50 \% \mathrm{C}$ & 0.69 & 4.06 & 1.90 & 0.065 & 0.018 & 0.007 & 0.33 \\
\hline $50 \% \mathrm{FB}+50 \% \mathrm{P}$ & 0.64 & 6.13 & 2.36 & 0.063 & 0.019 & 0.008 & 0.37 \\
\hline Mixture & 0.76 & 6.00 & 1.81 & 0.075 & 0.016 & 0.008 & 0.36 \\
\hline
\end{tabular}

Mixture: $25 \%$ faba bean $+25 \%$ lupine $+25 \%$ Chick pea $+25 \%$ peas

FB ( Faba bean), L ( Lupine), C ( Chickpea), P ( Peas).

Table (7): Nitrogenous constituents (\%) of raw materials used in tempe preparation.

\begin{tabular}{lllll}
\hline Legume & Total nitrogen & $\begin{array}{l}\text { Non protein } \\
\text { nitrogen }\end{array}$ & Protein nitrogen & True protein \\
\hline Faba bean & $4.05 \pm 0.20$ & $\mathbf{0 . 9 8} \pm 0.11$ & $3.07 \pm 0.35$ & $19.18 \pm 0.90$ \\
Lupine & $6.03 \pm 0.30$ & $1.37 \pm 0.13$ & $4.67 \pm 0.41$ & $29.15 \pm 1.00$ \\
Chickpea & $3.44 \pm 0.25$ & $1.36 \pm 0.12$ & $2.07 \pm 0.27$ & $12.93 \pm 0.60$ \\
Peas & $5.16 \pm 0.22$ & $1.30 \pm 0.10$ & $3.86 \pm 0.26$ & $24.13 \pm 0.85$ \\
\hline L.S.D.5\% & 0.30 & 0.13 & 0.42 & 1.02 \\
\hline
\end{tabular}

Table (8): Nitrogenous constituents (\%) of legumes mixture and their produced tempe.

\begin{tabular}{|c|c|c|c|c|}
\hline Legumes & Total nitrogen & $\begin{array}{l}\text { Non protein } \\
\text { nitrogen }\end{array}$ & Protein nitrogen & True protein \\
\hline $100 \% \mathrm{FB}$ & $4.05 \pm 0.20$ & $0.98 \pm 0.10$ & $3.07 \pm 0.25$ & $19.18 \pm 1.10$ \\
\hline $75 \% \mathrm{FB}+25 \% \mathrm{~L}$ & $4.55 \pm 0.23$ & $1.08 \pm 0.11$ & $3.46 \pm 0.10$ & $21.68 \pm 1.05$ \\
\hline $75 \% \mathrm{FB}+25 \% \mathrm{C}$ & $3.90 \pm 0.36$ & $1.06 \pm 0.12$ & $2.83 \pm 0.18$ & $17.62 \pm 0.95$ \\
\hline $75 \% \mathrm{FB}+25 \% \mathrm{P}$ & $4.33 \pm 0.31$ & $1.05 \pm 0.15$ & $3.27 \pm 0.21$ & $20.42 \pm 1.03$ \\
\hline $\mathbf{5 0} \% \mathrm{FB}+\mathbf{5 0} \% \mathrm{~L}$ & $5.07 \pm 0.42$ & $1.77 \pm 0.16$ & $3.87 \pm 0.46$ & $24.18 \pm 1.17$ \\
\hline $\mathbf{5 0} \% \mathbf{F B}+\mathbf{5 0} \% \mathbf{C}$ & $3.74 \pm 0.35$ & $1.16 \pm 0.15$ & $2.58 \pm 0.31$ & $16.05 \pm 0.86$ \\
\hline $50 \%$ FB $+50 \% P$ & $4.60 \pm 0.46$ & $1.02 \pm 0.10$ & $3.47 \pm 0.36$ & $21.65 \pm 0.90$ \\
\hline Mixture & $4.66 \pm 0.31$ & $1.23 \pm 0.15$ & $3.41 \pm 0.40$ & $21.35 \pm 0.96$ \\
\hline \multicolumn{5}{|l|}{ Fermented } \\
\hline $100 \% \mathrm{FB}$ & $5.02 \pm 0.50$ & $1.88 \pm 0.17$ & $3.14 \pm 0.30$ & $19.62 \pm 1.06$ \\
\hline $75 \% \mathrm{FB}+25 \% \mathrm{~L}$ & $5.05 \pm 0.38$ & $3.04 \pm 0.20$ & $2.01 \pm 0.21$ & $12.56 \pm 0.75$ \\
\hline $75 \% \mathrm{FB}+25 \% \mathrm{C}$ & $4.93 \pm 0.22$ & $2.43 \pm 0.18$ & $2.50 \pm 0.26$ & $15.62 \pm 0.70$ \\
\hline $75 \% \mathrm{FB}+25 \% \mathrm{P}$ & $5.03 \pm 0.39$ & $2.30 \pm 0.15$ & $2.73 \pm 0.20$ & $17.06 \pm 1.15$ \\
\hline $\mathbf{5 0} \% \mathbf{F B}+\mathbf{5 0} \% \mathrm{~L}$ & $5.58 \pm 0.50$ & $2.40 \pm 0.16$ & $3.18 \pm 0.38$ & $19.87 \pm 1.13$ \\
\hline $\mathbf{5 0} \% \mathrm{FB}+\mathbf{5 0} \% \mathrm{C}$ & $4.54 \pm 0.40$ & $2.52 \pm 0.10$ & $2.02 \pm 0.17$ & $13.75 \pm 0.65$ \\
\hline $50 \%$ FB $+50 \% P$ & $5.48 \pm 0.25$ & $3.19 \pm 0.20$ & $2.29 \pm 0.20$ & $14.31 \pm 0.80$ \\
\hline Mixture & $5.16 \pm 0.30$ & $3.73 \pm 0.25$ & $1.43 \pm 0.15$ & $8.94 \pm \overline{0} .65$ \\
\hline L.S.D. 5\% & 0.50 & 0.20 & 0.45 & 1.18 \\
\hline
\end{tabular}

Mixture: $25 \%$ faba bean $+25 \%$ lupine $+25 \%$ Check pea $+25 \%$ peas

FB ( Faba bean), L ( Lupine), C ( Chickpea), P ( Peas). 
The results in Table (4) show significant (p $\leq 0.05)$ reduction in all carbohydrate fractions, i.e. reducing sugars, starch, stachyose and raffinose. The reduction rates of reducing, starch, stachyose and reffinose ranged from 41 to $63 \%, 3$ to $7 \%, 47$ to $57 \%$ and 34 to $65 \%$, respectively. Such reduction in stachyose, raffinose and starch may be due to acidic hydrolysis during the pretreatment process and /or the enzymatic hydrolysis by fungi during the fermentation process. Similar results were obtained by Egounlety and Aworh (2003) who reported that about $50 \%$ of raffinose and more than $55 \%$ of stachyose were lost during pretreatment and fermentation of some legumes. The reduction of carbohydrate fractions might have been due to their utilization as an energy source by the fungi during fermentation (Omafurbe et al., 2000).

\subsection{Mineral content}

The changes in mineral contents of legumes, their mixtures and tempe produced are presented in Tables (5 and 6). It could be stated that faba beans have the highest $\mathrm{P} ; \mathrm{Zn}$ and $\mathrm{Cu}$, while lupine contains the highest $\mathrm{Na}, \mathrm{Mn}$ and $\mathrm{Fe}$, wherease peas have the highest content of $\mathrm{K}$ (Table 5). However, fermentation of different legumes by $R$. oligosporus induced a slight decrease in all mineral contents in tempe.

Ruiz-Teron and Owens (1996) reported that mineral content of soy bean did not alter appreciably after fermentation. The reduction of mineral content in tempe production may be due to the leaching out during preparation treatment and boiling process. The results are in agreement with those reported for mung bean by El-Sayed and El-Bagoury (2003).

\subsection{Nitrogenous constituents}

Results in Tables (7 and 8) illustrate the changes in nitrogenous conpounds of legumes, their mixture and tempe. It could be observed that lupine had the higher nitrogenous constituents followed by peas and faba bean, while chickpea had the lowest level.

On the other hand, fermentation process increased significantly $(\mathrm{p} \leq 0.05)$ the total nitrogen and non protein nitrogen contents in all legume mixtures. The maximum increase in total nitrogen and non protein nitrogen was found in the mixture of $50 \%$ faba bean $+50 \%$ lupine and mixture $(25 \%$ of each four legumes), respectively. Significant ( $p$ $\leq 0.05$ ) decrease was observed in protein nitrogen content and hence true protein specially in the case of the mixture. The increase of total nitrogen could be attributed to the hyphae of Rhizopus oligosporus. While, the increase in non protein nitrogen and the decrease in protein nitrogen may be due to hydrolysis of legumes protein by fungi proteolytic enzymes during fermentation. These results concided with the findings of Nowak and Szebiotko (1992); Komari (1993) and El-Sayed and El-Bagoury (2003).

Conclusion It could be concluded that tempe from mixture of different Egyptian traditional legumes can be produced. Fermentation process improved the nutritional quality of legume mixtures by increasing the protein and fiber content and reducing the flatulence sugars (stachyose and raffinose).

\section{REFERENCES}

AOAC (1990). Official Methods of Analysis, of the Association of Official Agricultural Chemists, $16^{\text {th }}$ ed published by the AOAC, North $19^{\text {th }}$. suit 210, Arlington, Virginia 222209, USA

Askar A. (1986). Faba beans (Vicia faba L.) and their role in the human diet. Food Nutr. Bull., 8 (3): $15-24$.

Campbell-Platt G. (1987). Fermented foods of the world. A Dictionary and Guide. London: Butterworths.

De-Reu J. C., Wold R. M. T., De-Groot J., Nout M. J., Ronibouts F. M. and Gryppen H. (1995). Protein hydrolysis during soybean tempe fermentation with Rhizopus oligosporus. J. Agric. Food Chem., 43: 2235 2241.

Dubois M., Gilles K.A., Hamilton J.K., Rebers P.A. and Smith, F. (1956). Colorimetric method for determination of sugars and related substances. Anal. Chem., 28: 350-356.

Egounlety M. and Aworh O. C. (2003). Effect of soaking, dehulling, cooking and fermentation with Rhizopus olyosporus on the oligosaccharides, trypsin inhibitor, phytic acid and tannins of soybean (Glycine max Merr), cowpea (Vigna unguiculata L. Walp) and ground bean Engineering, 56: 249 - 254.

El-Bagoury A. A., El-Sayed H. and Mohamed, G. H. (2001). Chemical and nutritional evaluation of mung bean tempe. J. Agric. Sci. Mansoura Univ., 26 (5): 2969 - 2981.

El-Sayed H. E. and El-Bagoury A. A. (2003). Evaluation of tempe produced by fermentation of soybean using two species of Rhizopus. J. Agric. Sci. Mansoura Univ., 28 (3): 1911 1926. 
Hachmeister K. A. and Fung D. Y. C. (1993). Tempe: A mold modified indigenous fermented food made from soybean and / or cereal grains. Critical Reviews in Microbiology, 19: $137-188$.

Komari (1993). Composition of lencaena tempe. ASEAN Food J., 8 (4): 157 - 158. [C.F., F. S. T. A., 26 (2): J 78].

Lindsey W. L. and Norwell M. E. (1969). A new DPTA-TEA soil test for zinc and iron. Agronomy Abstracts, 61, 84.

Liu K. (1997). Fermented oriental soy foods. In: Liu, K. (Ed.), Soybeans: Chemistry, Technology and Utilization, Chapman and Hall, New York, pp. 218 - 296.

Mital B.K. and Garg S. K. (1990). Tempetechnology and food value. Food Rev. Int., 6 (2): $213-224$.

Nout M. J. R. and Rombouts F. M. (1990). Recent developments in tempe research. J. Appl. Bacteriol., 69: 609-633.

Nowak J. and Szebiotko K. (1992). Some biochemical changes in tempe manufactureisolation of vitamin $\mathrm{B}_{12}$ producing bacteria Jarja, 22 (4): $310-316$.
Omafurbe B.O., Shonukan O.O. and Abiose S. H. (2000).Microbiological and biochemical changes in the traditional fermentation of soybean for daddawa-Nigerian food condiment. Food Microbiology, 17: 469 474.

Ruiz-Teron F. and Owens J. R. (1996). Chemical and enzymatic changes during the fermentation of bacteria-free soybean tempe. J. Sci. Food Agric., 17: 523 - 528.

Shurtleff W. and Aoyagi A. (1979). The Book of Tempe a super soy from Indonesia, New York: Harper and Row, USA.

Steel R.G. and Torrie J.H. (1980). In "Principles and Procedures of Statistics". $2^{\text {nd }}$ ed., New York, NY: McGraw-Hill Book Co., USA.

Steinkraus K. H. (1996). Indonesian tempe and related fermentation. In: Steinkraus, K. H., editor. Handbook of indigenous fermented foods, $2^{\text {nd }}$ Ed. New York: Marcel Dekker, pp. $7-110$.

Taussky H.H. and Shorr E. (1953). A microcolorimetric method for the determination of inorganic phosphorus. J. Biol. Chem., 202: 675-682.

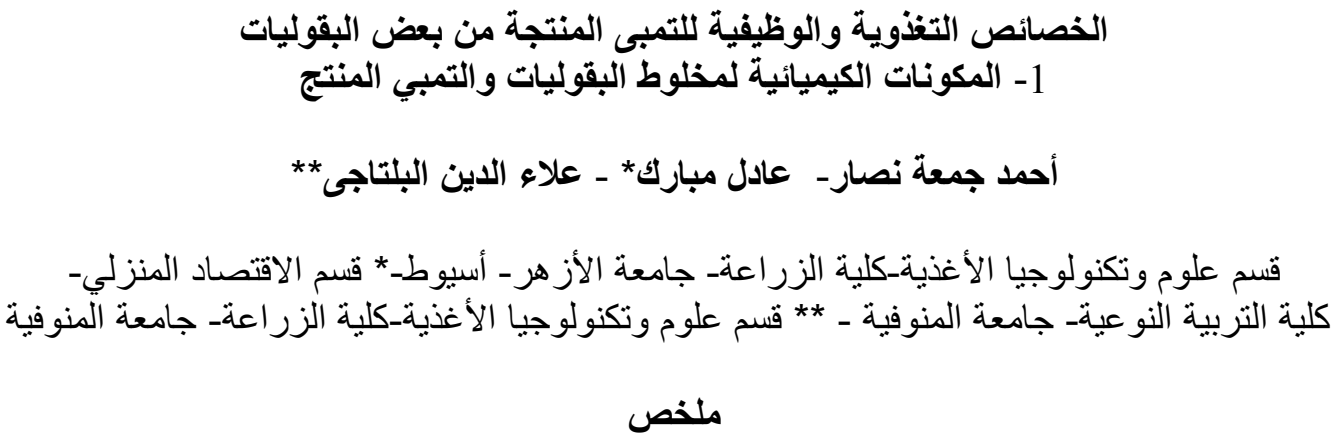

تعتبر إنتاج التمبي ـ كغذاء متخمر - إحدى الوسائل التكنولوجية لتصنيع البقوليات سو اء في صورة منفردة أو مخلوط منها ، وذللك بهدف زيادة قيمتها الغذائية لإعطاء منتجات تتمبز بارتفاع جودتها الغذائية و يُقبل عليها المستهلك.

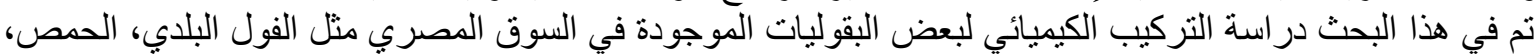

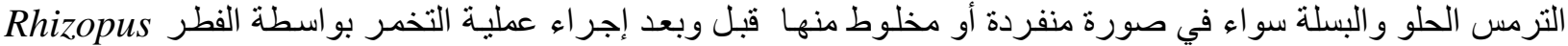
oligosporus

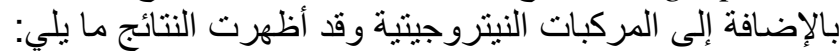

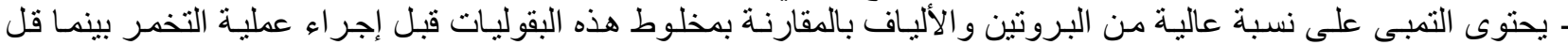

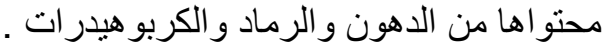

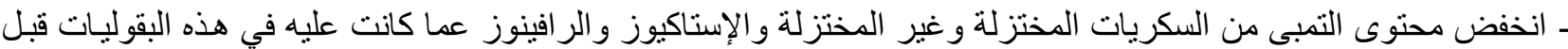
إجر اءء عملية التخمر. ـ لوحظ أن هناك نقص معنوي في نسبة النيتروجين غير البروتينى و البروتينى.

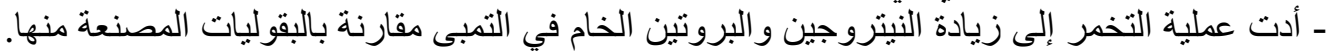
المجلة العلمية لكلية الزراعة - جامعة القاهرة - المجلد (58) العـدد الأول ينـاير (2007) 21-27. 